\title{
Chapter 6 \\ Relation Between Stress Drops and Depths of Strong Motion Generation Areas Based on Previous Broadband Source Models for Crustal Earthquakes in Japan
}

\author{
Toshimi Satoh and Atsushi Okazaki
}

\begin{abstract}
To aim at the advancement of strong motion predictions, we develop empirical relations between stress drops on strong motion generation areas (SMGAs) and depths of SMGAs based on previous broadband source models estimated by the empirical Green's function method. A total of 25 source models for 13 crustal earthquakes of Mw from 5.7 to 6.9 in Japan are used in this study. It is found that stress drops on SMGAs for reverse faults are larger than those for strikeslip faults on average. The average stress drops are 21.2 $\mathrm{MPa}, 13.3 \mathrm{MPa}$, and 18.0 MPa for reverse, strike-slip, and all types of faults, respectively. In the derived empirical relation for all types of faults, the stress drops increase by about $1 \mathrm{MPa}$ every $1 \mathrm{~km}$ in depth. This depth dependency is similar to the relation between stress drops on asperities and the depths of asperities derived by Asano and Iwata (Pure Appl Geophys, 168:105-116, 2011), and the absolute value is $4 \mathrm{MPa}$ larger than that by Asano and Iwata (Pure Appl Geophys, 168:105-116, 2011). The depth dependency of stress drops for reverse faults is stronger than that for strike-slip faults. The total area of SMGAs is about 0.8 times of the total area of asperities by Somerville et al. (Seismol Res Lett, 70:59-80, 1999). The result can be interpreted by frequency-dependent source radiations, since asperities are estimated from longer-period ( $>2 \mathrm{~s}$ ) strong motions than SMGAs, which are mainly estimated from strong motions in the period range from 0.1 to $5 \mathrm{~s}$.
\end{abstract}

Keywords Stress drop - Strong motion generation area - Crustal earthquake • Focal depth $\bullet$ Empirical Green's function method $\bullet$ Reverse fault $\bullet$ Strike-slip fault $\bullet$ Source model

T. Satoh $(\varangle)$

Shimizu Corporation, 4-17 Etchujima 3-chome, Koto-ku, Tokyo 135-8530, Japan

e-mail: toshimi.satoh@shimz.co.jp

A. Okazaki

Kansai Electric Power Company, 6-16, Nakanoshima 3-chome, Kita-ku, Osaka-shi, Osaka 530-0005, Japan

K. Kamae (ed.), Earthquakes, Tsunamis and Nuclear Risks,

DOI 10.1007/978-4-431-55822-4_6 


\subsection{Introduction}

Kamae and Irikura [1] estimated a broadband source model for the 1995 HyogokenNanbu earthquake (Mw6.9) to fit near-field strong motion records by forward modeling using the empirical Green's function method (e.g., Irikura [2]). Since Kamae and Irikura's pioneering work, many researchers have estimated broadband source models in the period range from about 0.1 to $5 \mathrm{~s}$ for the other big earthquakes using the empirical Green's function method. The broadband source models were composed of a few strong motion generation areas (SMGAs).

Irikura and Miyake [3] proposed the recipe for strong motion predictions. In the recipe, the source model was expressed by a few rectangular asperities and surrounding background areas. Here asperities were characterized from long-period heterogeneous kinematic slip models estimated by waveform inversion method using strong motion records in the period longer than about $2 \mathrm{~s}$ [4]. Asano and Iwata [5] studied on the relations between stress drops on asperities and depths of asperities for crustal earthquakes. Miyake et al. [6] showed that asperities coincide to SMGAs defined as areas that mainly generate strong ground motions. However, the period ranges to estimate asperities based on the waveform inversion results are relatively longer than those to estimate SMGAs by the empirical Green's function method. Therefore, we develop empirical relations between stress drops on SMGAs and depths of SMGAs based on the previous broadband source models estimated by the empirical Green's function method for crustal earthquakes in Japan to aim at the advancement of strong motion predictions.

\subsection{Data}

Data used in this study are shown in Table 6.1 [1, 6-34] and Fig. 6.1. A total of 22 articles on SMGAs [1, 6, 13, 16-34] for 13 crustal earthquakes of the moment magnitude Mw from 5.7 to 6.9 in 1995 to 2011 are used. The numbers of the strikeslip, reverse, and normal faults are six, six, and one, respectively. We independently treat each source model for the same earthquake, and so the total 25 source models are examined. We also independently treat each strong motion generation area. The stress drops on SMGAs estimated by Miyake et al. [6] are calculated assuming the single-asperity model. The others are calculated assuming single-crack models.

\subsection{Results}

Figure 6.2 shows the relations between stress drops on SMGAs and the top, center, and bottom depths of SMGAs for strike-slip faults and reverse faults. The number of SMGAs of each earthquake is one to three except for five by Hirai et al. [16]. The 
Table 6.1 List of earthquakes and references [1, 6-34]

\begin{tabular}{|c|c|c|c|c|c|}
\hline No. & Name of earthquake & Mw & $\begin{array}{l}\text { References on } \\
\mathrm{M}_{\mathrm{o}} \text { and } \mathrm{Mw}\end{array}$ & $\begin{array}{l}\text { Fault } \\
\text { type }\end{array}$ & $\begin{array}{l}\text { References on strong } \\
\text { motion generation areas }\end{array}$ \\
\hline \multirow[t]{2}{*}{1} & \multirow[t]{2}{*}{1995 Hyogoken-Nanbu } & \multirow[t]{2}{*}{6.9} & \multirow{2}{*}{$\begin{array}{l}\text { Sekiguchi } \\
\text { et al. [7] }\end{array}$} & \multirow{2}{*}{$\begin{array}{l}\text { Strike } \\
\text { slip }\end{array}$} & Kamae and Irikura [1] \\
\hline & & & & & Hirai et al. [16] \\
\hline 2 & $\begin{array}{l}1997 \text { Kagoshima-ken- } \\
\text { Hokuseibu (March) }\end{array}$ & 6.0 & Kuge et al. [8] & $\begin{array}{l}\text { Strike } \\
\text { slip }\end{array}$ & Miyake et al. [6] \\
\hline 3 & $\begin{array}{l}1997 \text { Yamaguchi-ken } \\
\text { Hokubu }\end{array}$ & 5.8 & F-net & $\begin{array}{l}\text { Strike } \\
\text { slip }\end{array}$ & Miyake et al. [6] \\
\hline 4 & $\begin{array}{l}1998 \text { Iwate-ken Nairiku } \\
\text { Hokubu }\end{array}$ & 5.9 & F-net & Reverse & Miyake et al. [6] \\
\hline \multirow[t]{2}{*}{5} & \multirow[t]{2}{*}{2000 Tottori-ken Seibu } & \multirow[t]{2}{*}{6.7} & \multirow{2}{*}{$\begin{array}{l}\text { Iwata and } \\
\text { Sekiguchi [9] }\end{array}$} & \multirow{2}{*}{$\begin{array}{l}\text { Strike } \\
\text { slip }\end{array}$} & Ikeda et al. [17] \\
\hline & & & & & Satoh and Irikura [18] \\
\hline \multirow[t]{2}{*}{6} & \multirow{2}{*}{$\begin{array}{l}2004 \text { Niigata-ken } \\
\text { Chuetsu }\end{array}$} & \multirow[t]{2}{*}{6.6} & \multirow{2}{*}{$\begin{array}{l}\text { Hikima and } \\
\text { Koketsu [10] }\end{array}$} & \multirow[t]{2}{*}{ Reverse } & Kamae et al. [19] \\
\hline & & & & & Satoh et al. [20] \\
\hline 7 & 2004 Rumoi & 5.7 & F-net & Reverse & Maeda and Sasatani [21] \\
\hline \multirow[t]{4}{*}{8} & \multirow{4}{*}{$\begin{array}{l}2005 \text { Fukuoka-ken } \\
\text { Seiho-oki }\end{array}$} & \multirow[t]{4}{*}{6.6} & \multirow{4}{*}{$\begin{array}{l}\text { Asano and } \\
\text { Iwata [5] }\end{array}$} & \multirow{4}{*}{$\begin{array}{l}\text { Strike } \\
\text { slip }\end{array}$} & Suzuki and Iwata [22] \\
\hline & & & & & Miyake et al. [23] \\
\hline & & & & & Satoh and Kawase [24] \\
\hline & & & & & Ikeda et al. [25] \\
\hline \multirow[t]{3}{*}{9} & \multirow[t]{3}{*}{2007 Noto Hanto } & \multirow[t]{3}{*}{6.6} & \multirow[t]{3}{*}{ Horikawa [12] } & \multirow[t]{3}{*}{ Reverse } & Kurahashi et al. [26] \\
\hline & & & & & Maeda et al. [27] \\
\hline & & & & & Ikeda et al. [25] \\
\hline \multirow[t]{4}{*}{10} & \multirow{4}{*}{$\begin{array}{l}2007 \text { Niigata-ken } \\
\text { Chuetsu-oki }\end{array}$} & \multirow[t]{4}{*}{6.6} & \multirow[t]{4}{*}{ Shiba [13] } & \multirow[t]{4}{*}{ Reverse } & Irikura [28] \\
\hline & & & & & Shiba [13] \\
\hline & & & & & $\begin{array}{l}\text { Yamamoto and Takenaka } \\
\text { [29] }\end{array}$ \\
\hline & & & & & Kawabe and Kamae [30] \\
\hline \multirow[t]{2}{*}{11} & \multirow{2}{*}{$\begin{array}{l}2008 \text { Iwate-Miyagi } \\
\text { Nairiku }\end{array}$} & \multirow[t]{2}{*}{6.8} & Horikawa [14] & Reverse & Kamae [31] \\
\hline & & & & & Irikura and Kurahashi [32] \\
\hline 12 & $\begin{array}{l}2011 \text { Shizuoka-ken } \\
\text { Tobu }\end{array}$ & 5.9 & F-net & $\begin{array}{l}\text { Strike } \\
\text { slip }\end{array}$ & Somei et al. [33] \\
\hline 13 & $\begin{array}{l}2011 \text { Fukushima-ken } \\
\text { Hamadori }\end{array}$ & 6.6 & Hikima [15] & Normal & Somei et al. [34] \\
\hline
\end{tabular}

stress drops are less than $30 \mathrm{MPa}$ except for those for the 2007 Noto Hanto earthquake estimated by Maeda et al. [27]. Although source models for the same earthquake are different among researchers, large SMGAs tend to be located at deep places.

Figure 6.3a shows the relations between the stress drops and the center depths of SMGAs for all types of earthquakes including a normal-fault earthquake and regression relations. The average stress drops are $21.2 \mathrm{MPa}$ with standard error of 9.2 $\mathrm{MPa}, 13.3 \mathrm{MPa}$ with standard error of 5.3 $\mathrm{MPa}$, and 18.0 $\mathrm{MPa}$ with standard error of 8.6 MPa for reverse, strike-slip, and all types of faults, respectively. The average stress drop on SMGAs of $18.0 \mathrm{MPa}$ in this study is larger than average 


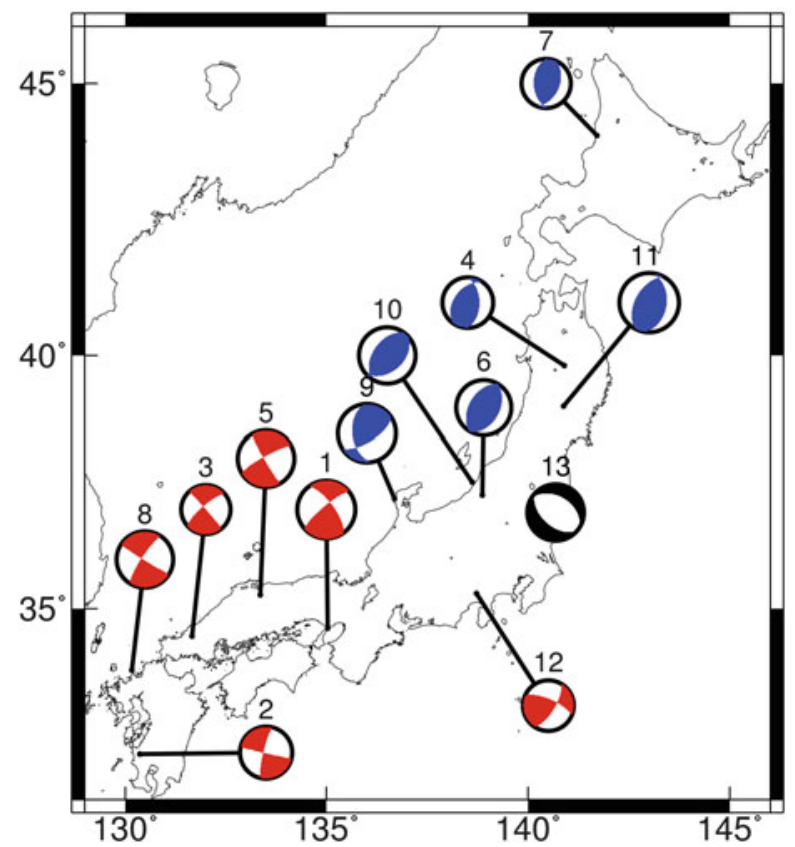

Fig. 6.1 Epicenters by JMA and focal mechanisms by the Global CMT Project for No.1 earthquake and by F-net for the other earthquakes
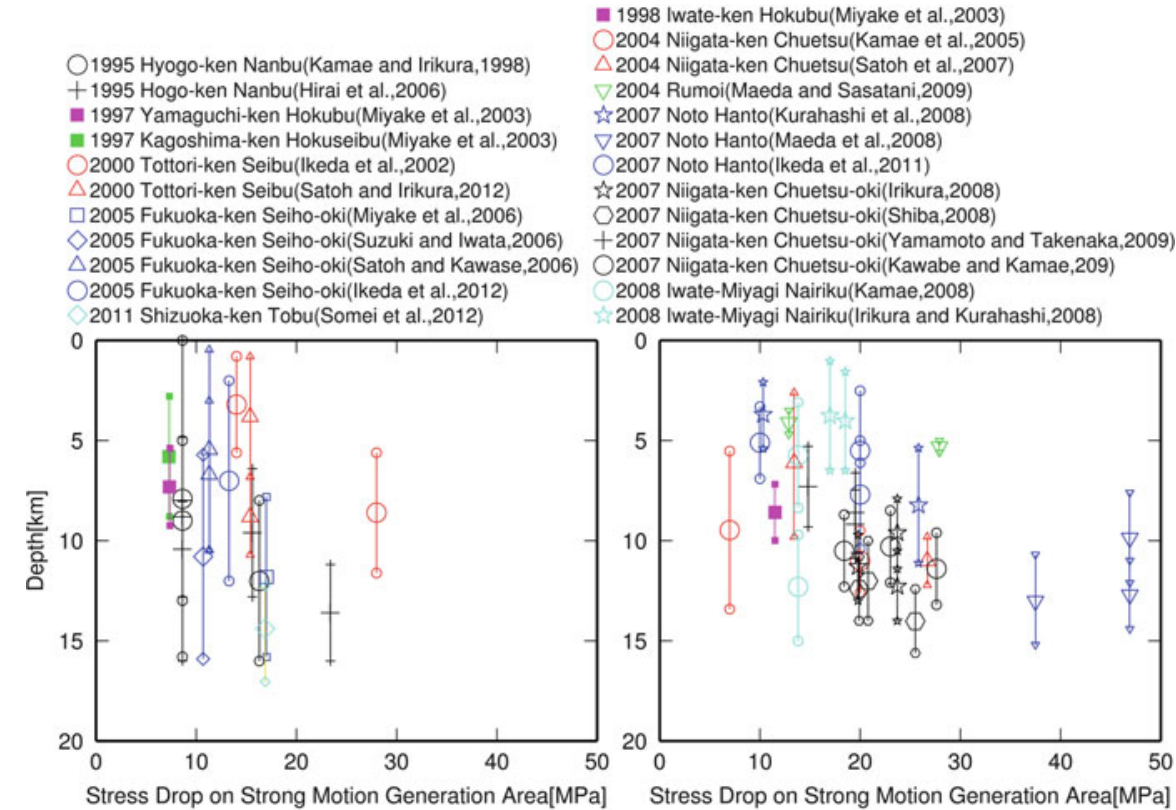

Fig. 6.2 Relations between stress drops and depths of SMGAs for strike-slip faults (left) and reverse faults (right). Large symbols denote the center depth of each SMGA. Small symbols denote the top and bottom depths of each SMGA 

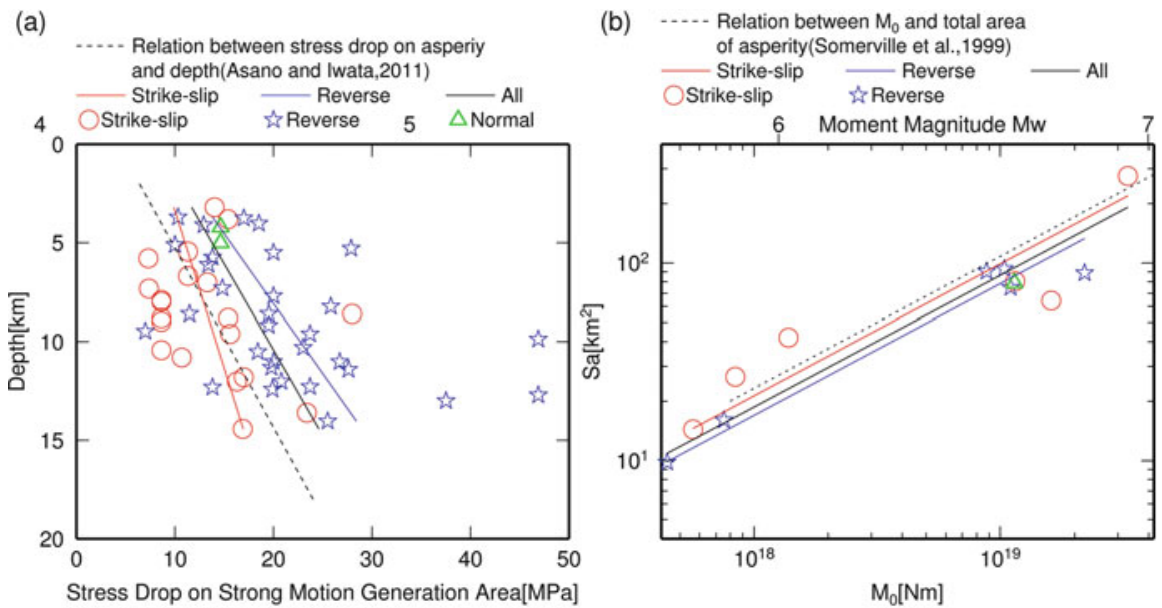

Fig. 6.3 (a) Relations between stress drops and the center depths of SMGAs. (b) Relations between $\mathrm{M}_{\mathrm{o}}$ and total area of SMGAs

stress drop on asperities of $10.5 \mathrm{MPa}$ in the recipe by Irikura and Miyake [3]. The average center depths are $8.90 \mathrm{~km}, 8.65 \mathrm{~km}$, and $8.65 \mathrm{~km}$ for reverse, strike-slip, and all types of faults, respectively. The relations between stress drops $\Delta \sigma_{\mathrm{a}}[\mathrm{MPa}]$ on SMGAs and the center depths $\mathrm{h}[\mathrm{km}]$ are written as

$$
\begin{gathered}
\Delta \sigma_{\mathrm{a}}=0.63 \mathrm{~h}+7.88 \quad(\text { standard error }=5.26) \quad \text { for strike-slip faults, } \\
\left.\Delta \sigma_{\mathrm{a}}=1.42 \mathrm{~h}+8.54 \quad \text { (standard error }=8.39\right) \quad \text { for reverse faults, } \\
\Delta \sigma_{\mathrm{a}}=1.15 \mathrm{~h}+7.98 \quad(\text { standard error }=8.05) \quad \text { for all types of faults }
\end{gathered}
$$

The depth dependency for reverse faults is stronger than that for strike-slip faults. The stress drops for reverse faults is larger than those for strike-slip faults at the same depth. Although the standard errors [MPa] of the empirical relations are large, Eq. (6.3) means that stress drops increase by about $1 \mathrm{MPa}$ every $1 \mathrm{~km}$ in depth. The empirical relations between stress drops on asperities $\Delta \sigma_{\text {asp }}$ and the center depths derived by Asano and Iwata [5] for crustal earthquakes in Japan shown in Fig. 6.3a is

$$
\Delta \sigma_{\text {asp }}=1.10 \mathrm{~h}+4.2 \quad(\text { standard error }=7.2) \quad \text { for all types of faults }
$$

The depth dependency of the equations of (6.3) and (6.4) are similar, and the absolute value of the stress drop on SMGAs is about $4 \mathrm{MPa}$ larger than the stress drop on asperities.

We also derive the relations between seismic moment $\mathrm{M}_{\mathrm{o}}[\mathrm{Nm}]$ and total area of SMGAs $S_{\mathrm{a}}\left[\mathrm{km}^{2}\right]$ as shown in Fig. 6.3b in which $S_{\mathrm{a}}$ is the average for each earthquake. The equations derived by constraining the slop to be $1 / 3$ are written as 
$S_{\mathrm{a}}=4.57 \times 10^{-16}\left(\mathrm{M}_{\mathrm{o}} \times 10^{7}\right)^{2 / 3}($ common logarithm of standard error $=0.18)$

for strike-slip faults

$S_{\mathrm{a}}=3.64 \times 10^{-16}\left(\mathrm{M}_{\mathrm{o}} \times 10^{7}\right)^{2 / 3} \quad($ common logarithm of standard error $=0.09)$

for reverse faults

$S_{\mathrm{a}}=4.02 \times 10^{-16}\left(\mathrm{M}_{\mathrm{o}} \times 10^{7}\right)^{2 / 3} \quad($ common logarithm of standard error $=0.15)$

for all types of faults

The scaling law for total area of asperities $S_{\text {asp }}$ by Somerville et al. [4] shown in Fig. $6.3 \mathrm{~b}$ is written as

$$
S_{\text {asp }}=5.00 \times 10^{-16}\left(\mathrm{M}_{\mathrm{o}} \times 10^{7}\right)^{2 / 3}
$$

$S_{\mathrm{a}}$ for strike-slip, reverse, and all types of faults are about $0.91,0.73$, and 0.80 times of $S_{\text {asp }}$ by Somerville et al. [4]. Although the standard error is large, $S_{\text {a }}$ for each reverse fault is smaller than $S_{\text {asp }}$ by Somerville et al. [4]. SMGAs are source models for strong motions in the period range from 0.1 to $5 \mathrm{~s}$, while the asperities are source models for strong motions in the period longer than about $2 \mathrm{~s}$. Therefore, the result that total area of SMGAs is smaller than total area of asperities is interpreted by frequency-dependent source radiations [35].

Short-period spectral level $A$ which means the flat level of acceleration source spectrum [36] is proportional to stress drop and square root of total area of SMGAs (or asperities). Considering the equations of (6.1), (6.2), (6.5), and (6.6), $A$ for reverse faults is larger than $A$ for strike-slip faults. Satoh [35] showed the same results from strong motion records for big crustal earthquakes in Japan using the spectral inversion method. McGarr [37] showed that peak ground velocities PGVs normalized by $\mathrm{M}_{\mathrm{o}}{ }^{1 / 3}$ and hypocentral distances depend on focal depths and are larger for reverse faults than normal faults. He pointed out that these results are expected from frictional laws. In addition he pointed out that data of strike-slip faults were insufficient in his analysis, but the normalized PGVs for strike-slip faults would lie between those for reverse and normal faults. Our results are qualitatively consistent with McGarr's results, although site effects were not considered in McGarr's results. 


\subsection{Conclusions}

We developed empirical relations between stress drops on SMGAs and depths of SMGAs based on previous broadband source models estimated by the empirical Green's function method. A total of 25 source models for 13 crustal earthquakes of Mw from 5.7 to 6.9 in Japan are used in this study. As a result it is found that stress drops on SMGAs for reverse faults are larger than those for strike-slip faults on average. The average stress drops are 21.2 $\mathrm{MPa}, 13.3 \mathrm{MPa}$, and 18.0 $\mathrm{MPa}$ for reverse, strike-slip, and all types of faults, respectively. In the derived empirical relation for all types of faults, the stress drops increase by about $1 \mathrm{MPa}$ every $1 \mathrm{~km}$ in depth. The depth dependency of stress drops for reverse faults is stronger than that for strike-slip faults. We also showed that the total area of SMGAs is about 0.8 times of the total area of asperities by Somerville et al. [4]. This result can be interpreted by frequency-dependent source radiations, since asperities are estimated from longer-period strong motions $(>2 s)$ than SMGAs. The empirical relations derived in this study would be useful for advancement of strong motion predictions for crustal earthquakes by considering together with regional differences and uncertainties.

Acknowledgments We use focal mechanisms estimated by the Global CMT Project and F-net by NIED and epicenters estimated by JMA. Figures are drawn by GMT [38]. This study is a part of cooperative research of 12 electric power companies.

Open Access This chapter is distributed under the terms of the Creative Commons Attribution Noncommercial License, which permits any noncommercial use, distribution, and reproduction in any medium, provided the original author(s) and source are credited.

\section{References}

1. Kamae K, Irikura K (1998) Source model of the 1995 Hyogo-ken Nanbu earthquake and simulation of near-source ground motion. Bull Seismol Soc Am 88:400-412

2. Irikura K (1986) Prediction of strong acceleration motions using empirical Green's function. In: Proceedings of the 7th Japan earthquake engineering symposium, Tokyo, Japan, 10-12 Dec 1986, pp 151-156

3. Irikura K, Miyake H (2011) Recipe for predicting strong ground motion from crustal earthquake scenarios. Pure Appl Geophys 168:85-104. doi:10.1007/s00024-010-0150

4. Somerville PG, Irikura K, Graves R, Sawada S, Wald D, Abrahamson D, Iwasaki Y, Kagawa T, Smith N, Kowada A (1999) Characterizing crustal earthquake slip models for the prediction of strong ground motion. Seismol Res Lett 70:59-80

5. Asano K, Iwata T (2011) Characterization of stress drops on asperities estimated from the heterogeneous kinematic slip model for strong motion prediction for inland crustal earthquakes in Japan. Pure Appl Geophys 168:105-116

6. Miyake H, Iwata T, Irikura K (2003) Source characterization for broadband ground-motion simulation: Kinematic heterogeneous source model and strong motion generation area. Bull Seismol Soc Am 93:2531-2545 
7. Sekiguchi H, Irikura K, Iwata T (2002) Source inversion for estimating the continuous slip distribution on a fault - introduction of Green's functions convolved with a correction function to give moving dislocation effects in subfaults. Geophys J Int 150:377-391

8. Kuge K, Iwata T, Irikura K (1997) Automatic estimation of earthquake source parameters using waveform data from the K-NET, Programme and Abstracts, the Seismological Society of Japan B16 (in Japanese)

9. Iwata T, Sekiguchi H (2002) Source model of the 2000 Tottori-ken Seibu earthquake and nearsource strong ground motion. In: Proceedings of the 11th Japan earthquake engineering symposium, Tokyo, Japan, 20-22 Nov 2002, pp 125-128 (in Japanese with English abstract)

10. Hikima K, Koketsu K (2005) Rupture processes of the 2004 Chuetsu (mid-Niigata prefecture) earthquake, Japan: a series of events in a complex fault system. Geophys Res Lett 32, L18303

11. Asano K, Iwata T (2006) Source process and near-source ground motions of the 2005 West Off Fukuoka Prefecture earthquake. Earth Planets Space 58:93-98

12. Horikawa H (2008) Characterization of the 2007 Noto Hanto, Japan, earthquake. Earth Planets Space 60:1017-1022

13. Shiba Y (2008) Source process and broadband strong motions during the Niigata-ken Chuetsuoki earthquake in 2007, CRIEPI Research Report N08007:1-21 (in Japanese with English abstract)

14. Horikawa H (2009) Source process of the 2008 Iwate-Miyagi Nairiku earthquake as deduced from strong motion data (preliminary report), Report of CCEP 81:139-141 (in Japanese)

15. Hikima K (2012) Rupture process of the April 11, 2011 Fukushima Hamadori earthquake (Mj 7.0) - two fault planes inferred from strong motion and relocated aftershocks. Zisin, Second Series 64:243-256

16. Hirai T, Kamae K, Naganuma T, Ito S, Nishioka T, Irikura K (2006) Simulation of strong ground motion due to the 1995 Hyogo-ken-Nanbu Earthquake by using characterized source model with branch fault. J JAEE 6(3):1-11 (in Japanese with English abstract)

17. Ikeda T, Kamae K, Miwa S, Irikura K (2002) Source characterization and strong ground motion simulation of the 2000 Tottori-ken Seibu earthquake using the empirical Green's function method. J Struct Constr Eng (Trans Archit Inst Japan) 561:37-45 (in Japanese with English abstract)

18. Satoh T, Irikura K (2012) Short-period spectral level and the total area of strong motion generation area considering type-of-earthquakes and style-of-faultings, Programme and Abstracts, the Seismological Society of Japan:253 (in Japanese)

19. Kamae K, Ikeda T, Miwa S (2005) Source model composed of asperities for the $2004 \mathrm{Mid}$ Niigata Prefecture, Japan, earthquake $\left(\mathrm{M}_{\mathrm{JMA}}=6.8\right)$ by the forward modeling using the empirical Green's function. Earth Planets Space 57:533-538

20. Satoh T, Hijikata K, Uetake T, Tokumitsu R, Dan K (2007) Cause of large peak ground acceleration of the 2004 Niigata-ken Chuetsu earthquake by broadband source inversion Part2. Middle and short-period source inversion, Summaries of technical papers of Annual Meeting, AIJ, B-2:365-366 (in Japanese)

21. Maeda T, Sasatani T (2004) Strong ground motions from an Mj 6.1 inland crustal earthquake in Hokkaido, Japan: the 2004 Rumoi earthquake. Earth Planets Space 61:689-701

22. Suzuki W, Iwata T (2006) Source model of the 2005 west off Fukuoka prefecture earthquake estimated from the empirical Green's function simulation of broadband strong motions. Earth Planets Space 58:99-104

23. Miyake H, Tanaka Y, Sakaue M, Koketsu K, Ishigaki Y (2006) Empirical Green's function simulation of broadband ground motions on Genkai Island during the 2005 West Off Fukuoka prefecture earthquake. Earth Planets Space 58:1637-1642

24. Satoh T, Kawase H (2006) Estimation of characteristic source model of the 2005 west off Fukuoka prefecture earthquake based on empirical Green's function method. In: Proceedings of the 12th Japan earthquake engineering symposium, Tokyo, Japan, 3-5 Nov 2006, pp 170-173 (in Japanese with English abstract) 
25. Ikeda T, Kamae K, Irikura K (2011) Source modeling using the empirical Green's function method and strong ground motion estimation considering nonlinear site effect: an application to the 2005 west off Fukuoka prefecture earthquake and the 2007 Noto Hanto earthquake. J Struct Constr Eng (Trans Archit Inst Japan) 665:1253-1261 (in Japanese with English abstract)

26. Kurahashi S, Masaki K, Irikura K (2008) Source model of the 2007 Noto-Hanto earthquake (Mw 6.7) for estimating broad-band strong ground motion. Earth Planets Space 60:89-94

27. Maeda T, Ichiyanagi M, Takahashi H, Honda R, Yamaguchi T, Kasahara M, Sasatani T (2008) Source parameters of the 2007 Noto Hanto earthquake sequence derived from strong motion records at temporary and permanent stations. Earth Planets Space 60:1011-1016

28. Irikura K (2008) http://www.kojiro-irikura.jp/pdf/chikyuokangaerukai.pdf. Accessed 5 Jan 2015 (in Japanese)

29. Yamamoto Y, Takenaka H (2009) Source modeling of the 2007 Niigataken Chuetsu oki earthquake using the empirical Green's function method. Zisin, Second Series 62:47-59 (in Japanese with English abstract)

30. Kawabe H, Kamae K (2010) Source modeling and 3D ground motion simulation of the 2007 Niigataken Chuetsu-oki earthquake (Mj6.8). In: Proceedings of the 13th Japan earthquake engineering symposium, Tsukuba, Japan, 17-10 Nov 2010, pp 1899-1906 (in Japanese with English abstract)

31. Kamae K (2008) http://www.rri.kyoto-u.ac.jp/jishin/iwate_miyagi_1.html. Accessed 5 Jan 2015 (in Japanese)

32. Irikura K, Kurahashi S (2008) Modeling of source fault and generation of high-acceleration ground motion for the 2008 Iwate-miyagi-nairiku earthquake, Programme and Abstracts, JSAF Fall Meeting: 8-11, t. Accessed 5 Jan 2015 (in Japanese)

33. Somei K, Miyakoshi K, Kamae K (2012) Source model of the 2011 East Shizuoka prefecture, Japan, earthquake by using the empirical Green's function method. Japan Geoscience Union Meeting, SSS26-P27

34. Somei K, Miyakoshi K, Irikura K (2011) Estimation of source model and strong motion simulation for the 2011 East Fukushima Prefecture Earthquake, Programme and Abstracts, the Seismological Society of Japan, Fall Meeting:211 (in Japanese)

35. Satoh T (2010) Scaling law of short-period source spectra for crustal earthquakes in Japan considering style of faulting of dip-slip and strike-slip. J Struct Constr Eng (Trans Archit Inst Japan) 651:923-932 (in Japanese with English abstract)

36. Dan K, Watanabe M, Sato T, Ishii T (2001) Short-period source spectra inferred from variableslip rupture models and modeling of earthquake faults for strong motion prediction by semiempirical method. J Struct Constr Eng (Trans Archit Inst Japan) 545:51-62 (in Japanese with English abstract)

37. McGarr A (1984) Scaling of ground motion parameters, state of stress, and focal depth. J Geophys Res 89:6969-6979. doi:10.1029/JB089iB08p06969

38. Wessel P, Smith WHF (1998) New, improved version of generic mapping tools released. Eos Trans Am Geophys Union 79:579 